REVISTA ARA N 4 . OUTONO+INVERNO, 2018 • GRUPO MUSEU/PATRIMÔNIO FAU-USP

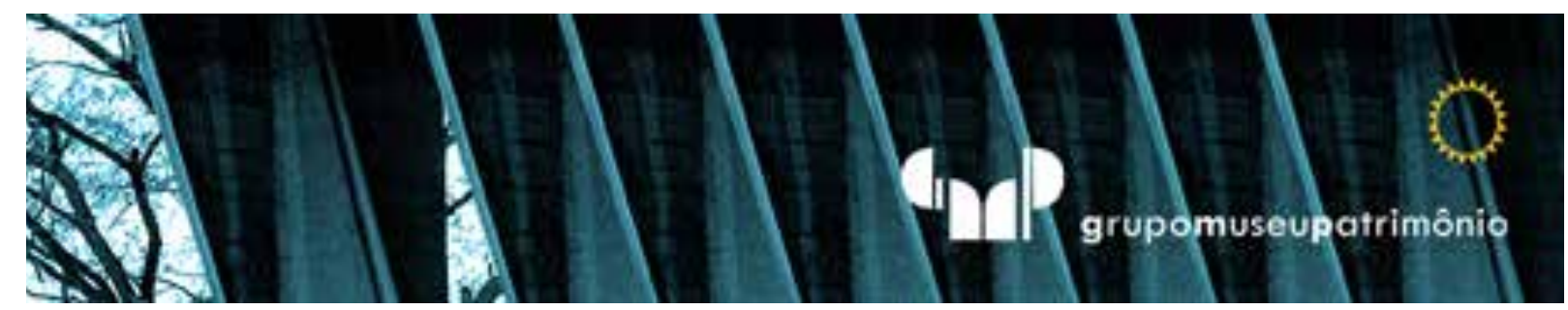

\title{
Assim vivem as corruíras
}

\section{Así viven los cucaracheros}

\author{
Thus wrens live
}

Mario Rui Feliciani

Fotógrafo, Jundiaí, SP, Brasil, mruifel@gmail.com, www.mruifotos.com 


\section{Resumo}

Ensaio fotográfico. A cidade grande e a cidade de médio porte, com fortes marcas rurais de reserva florestal e plantações de frutas, percorridas pelo olhar perscrutador. As práticas do espaço (na expressão de Michel de Certeau) e alguns de seus praticantes, principalmente os excluídos da função econômica da cidade, da produção.

Palavras-Chave: Fotografia. Ocupação. Urbano. Rural. Cidadania.

\section{Abstract}

Photo essay. The big city and the mid-sized town with strong rural marks of forest reserve and fruit plantations, covered by a searching eye. The practices of the space (in the expression of Michel de Certeau) and some of its practitioners, especially those excluded from the economic function of the city and from production.

Keywords: Photography. Occupation. Urban. Rural. Citizenship.

\section{Resumen}

Ensayo fotográfico. La ciudad grande y la ciudad de mediano porte, con fuertes marcas rurales de reserva forestal y plantaciones de frutas, recorridas por la mirada escrutadora. Las prácticas del espacio (en la expresión de Michel de Certeau) y algunos de sus practicantes, principalmente los excluidos de la función económica de la ciudad, de la producción.

Palabras clave: Fotografía. Ocupación. Urbano. Rural. Ciudadanía. 


\section{O ESPAÇO TOMADO PELOS MIÚDOS}

O que mais há na terra, é paisagem. José Saramago $(2013$, p.9)

\footnotetext{
O
} espaço se toma pelas pessoas. Por mais que se coíba esse seu furto legítimo pelos que nele vivem, o formigueiro humano acaba se impondo. Eliminam-se algumas formigas, mas outras trepam por baixo da calça. Escapam o risco de amor na árvore, a pintura no muro, o fungo tolerado ou a simples disposição do objeto deslocado. Tudo o que é tratado com descaso pelo poder institucional, mas que imprime ao lugar o que nele pode haver de caseiro, reconhecível.

E tudo se liga ao chão. O povo institucionalizado se eleva. O povo miúdo ${ }^{1}$ se agarra ao térreo, à calçada, ao asfalto.

1 A expressão "miúdo" neste texto não significa "criança". É metárofora afetiva usada para se referir à parcela dos cidadãos alijada de todo ou quase todo privilégio social ou econômico. 
A corruíra é boa metáfora. É pássaro que sabe voar, mas gosta de andar.

Miúdo, rápido, fuçador de cantinhos. Cor de miscigenado, camuflado na terra.

Seu outro nome é garrincha, outro rápido, que praticou sua arte nos pequenos espaços. Herói nacional. Herói improvável.

Bicho pequeno, "tem que ficar esperto". Sempre alerta.

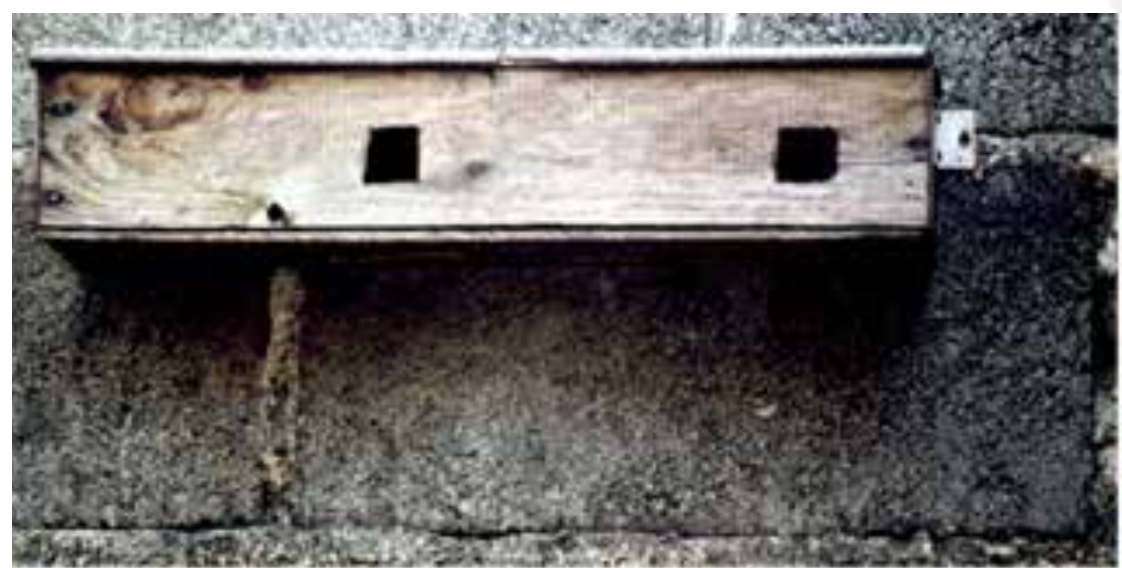

Figura 1: Ninho construído para corruíra. Se o bloco tem 19 de altura, as aberturas para entrada têm $2.5 \mathrm{~cm}$ de lado. Não podem ser maiores ou ela não se sente segura

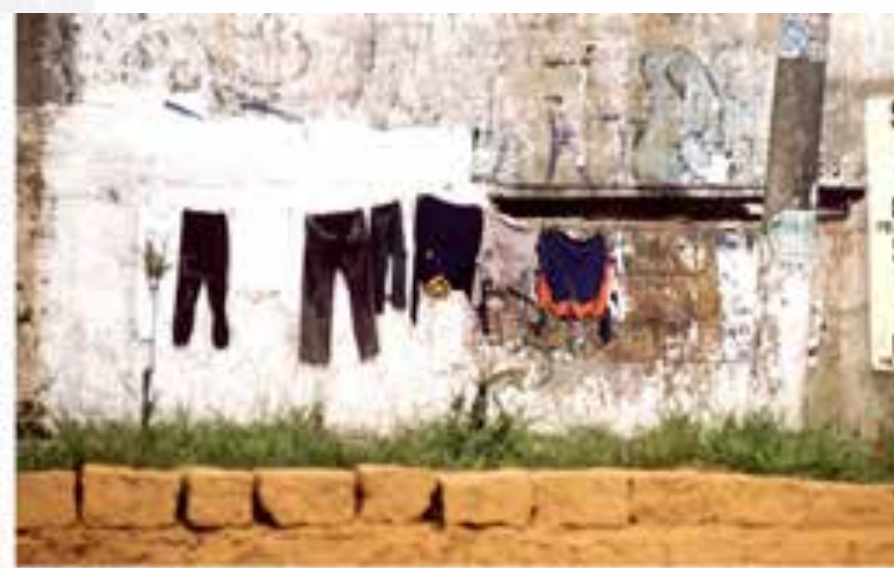

Figura 2

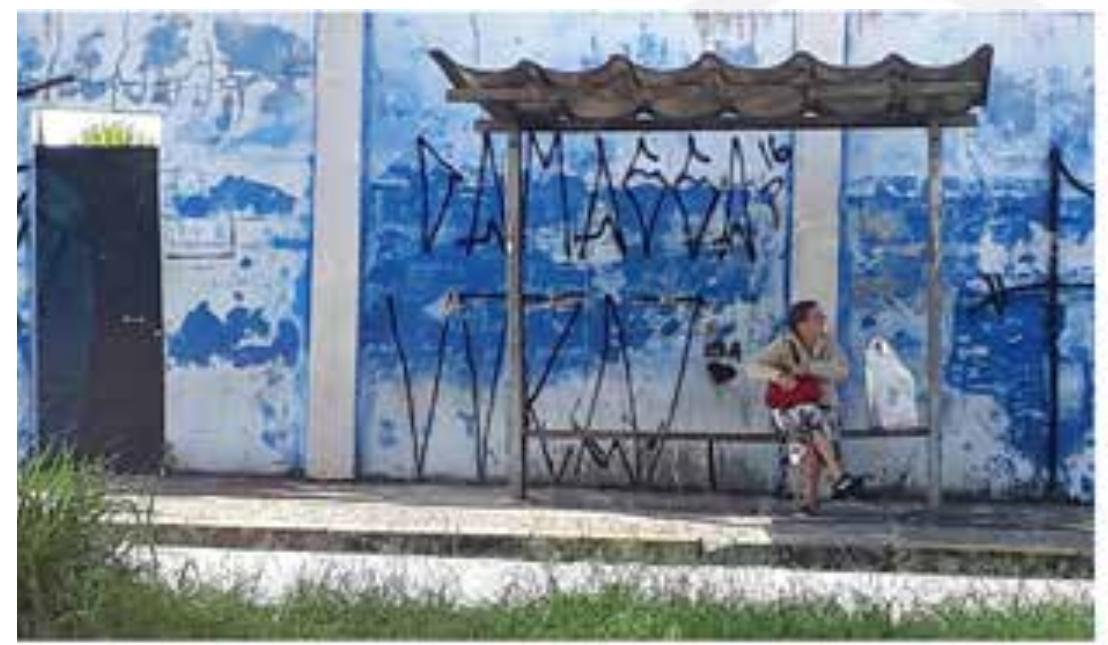

Figura 3

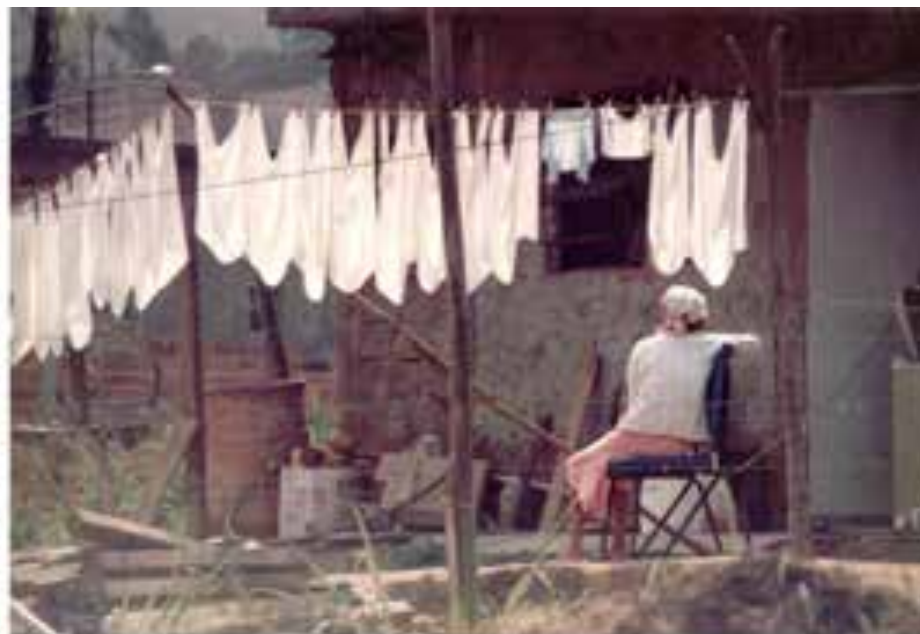

Figura 4 


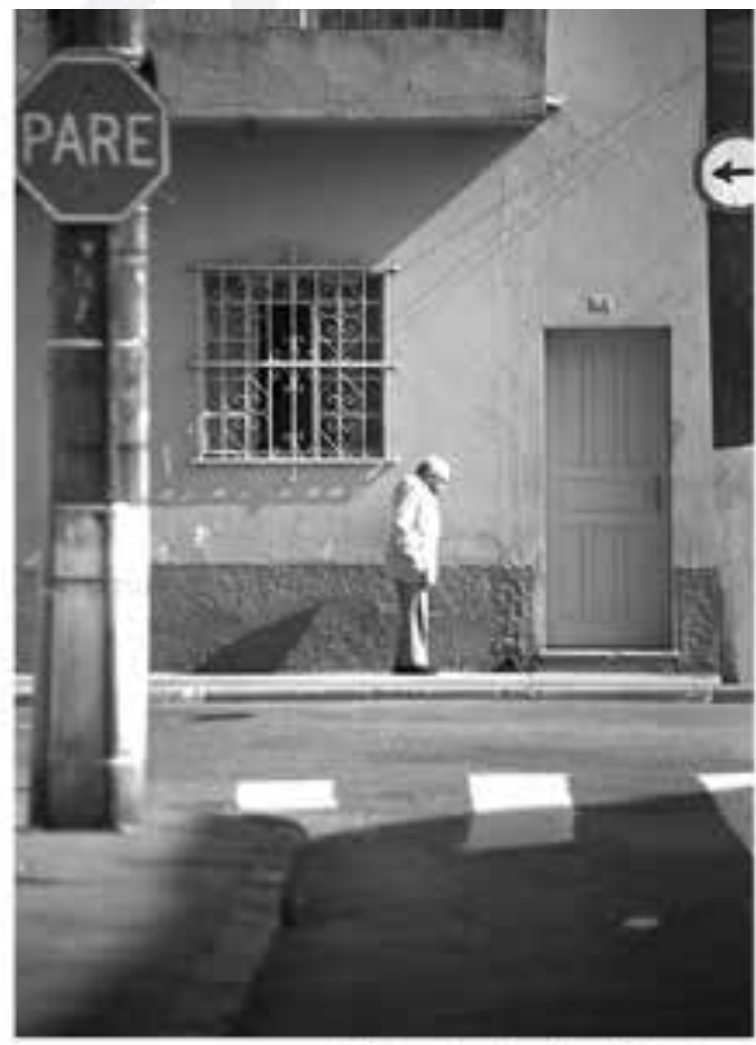

Figura .5: desobediência

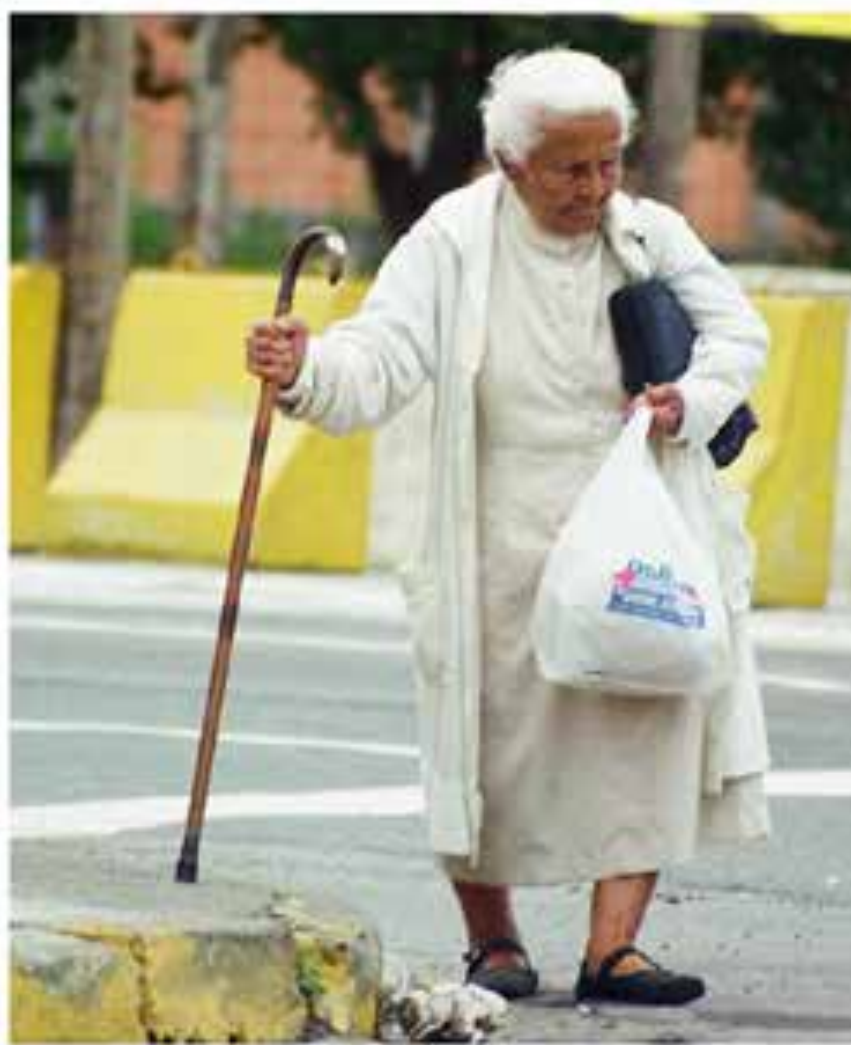

Figura 6: pé ante pé

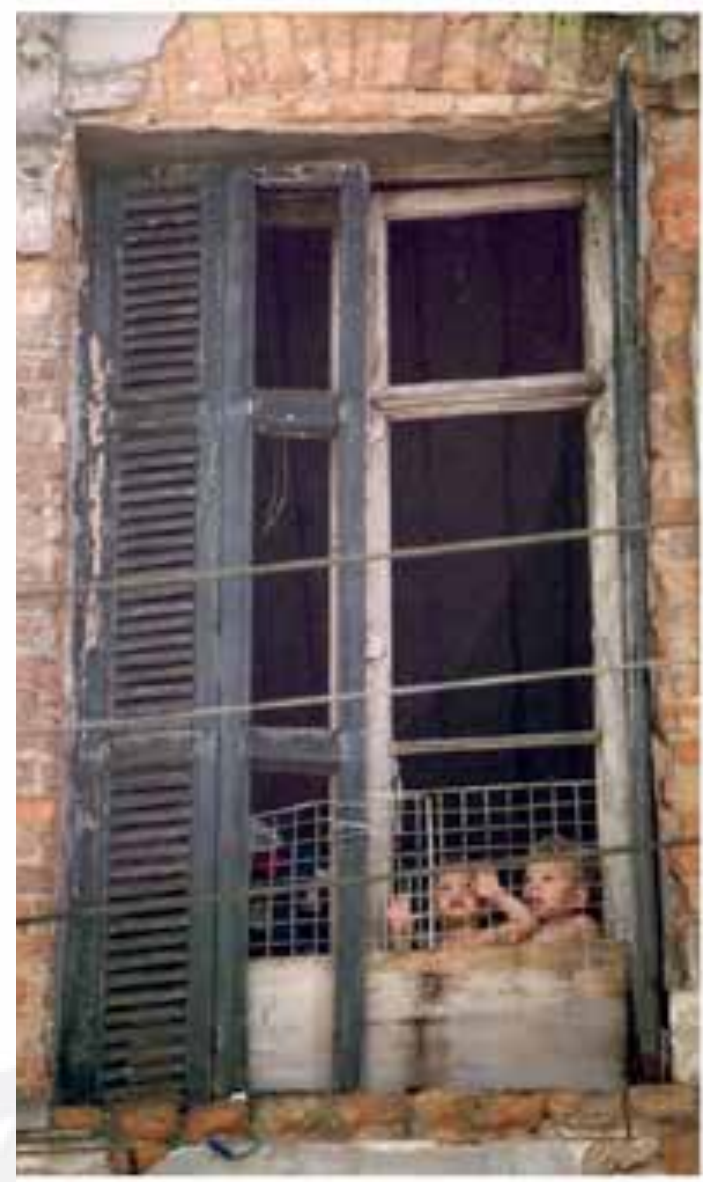

Figura 7: já vamos

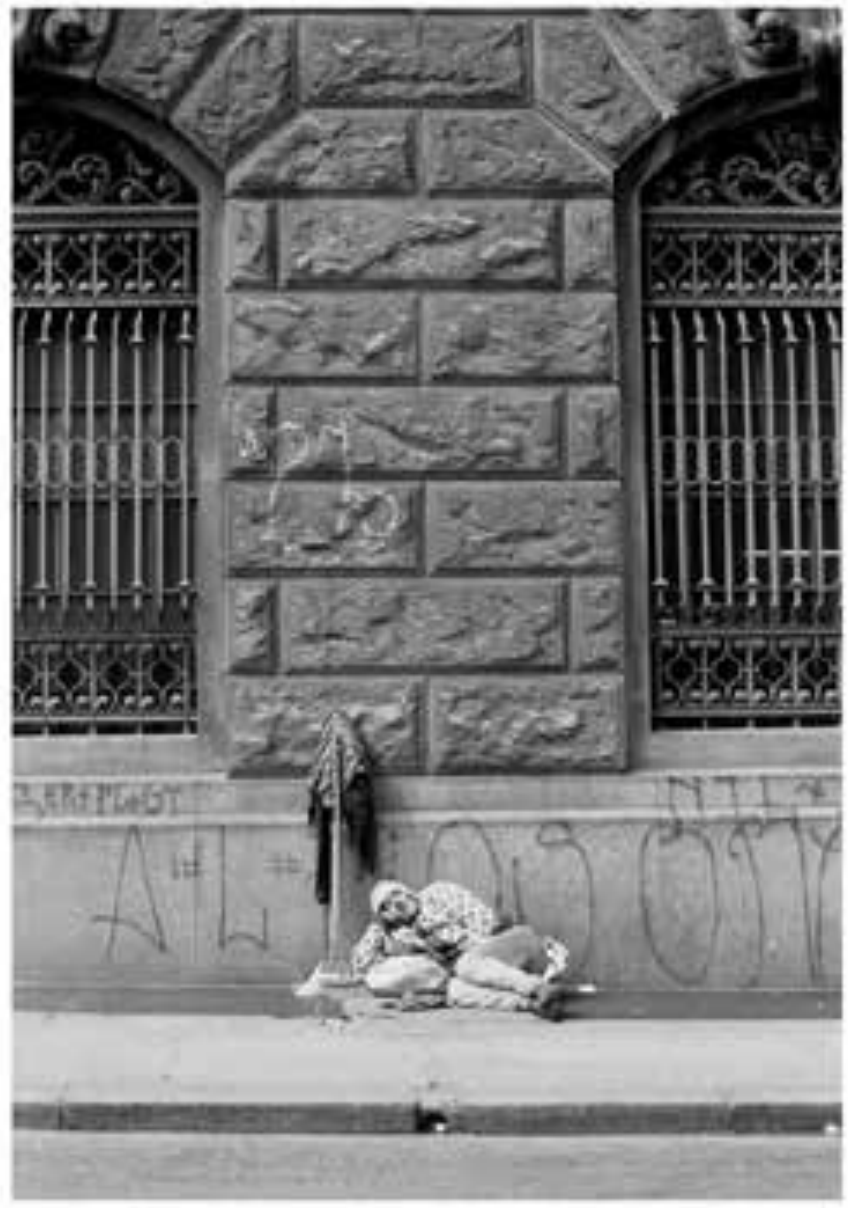

Figura 8: pausa 


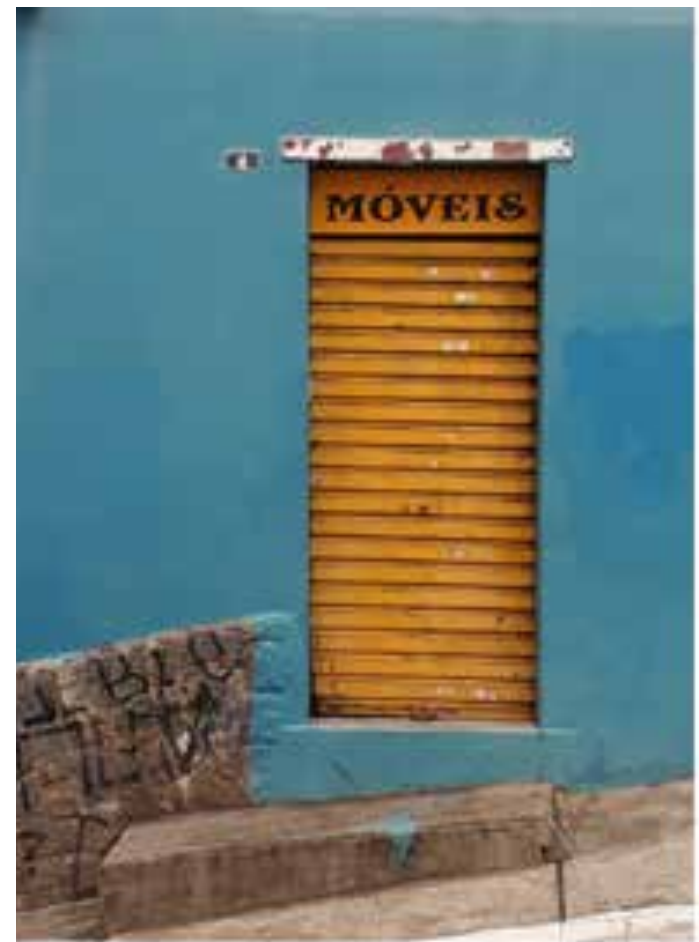

Figura 9

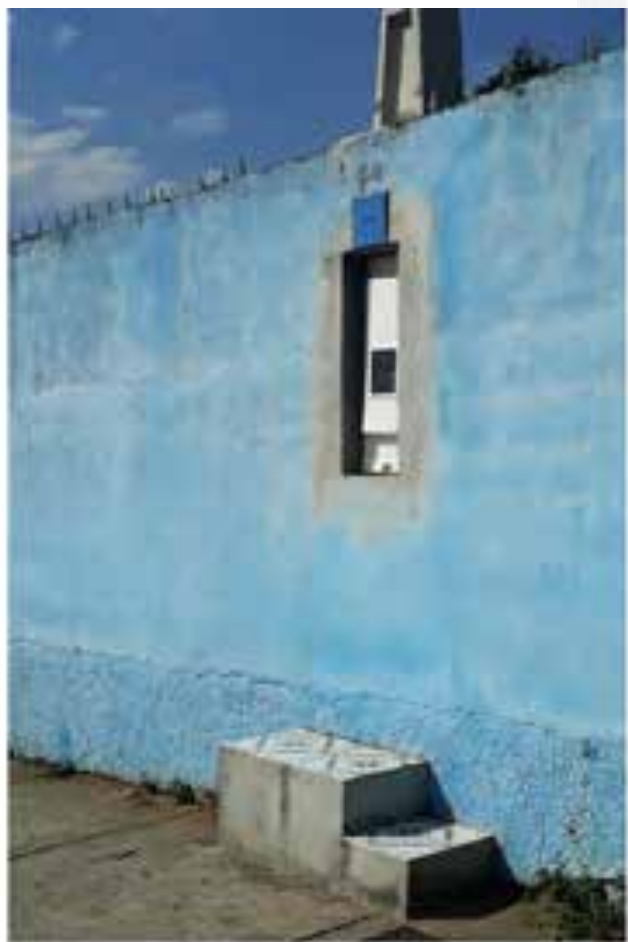

Figura 10

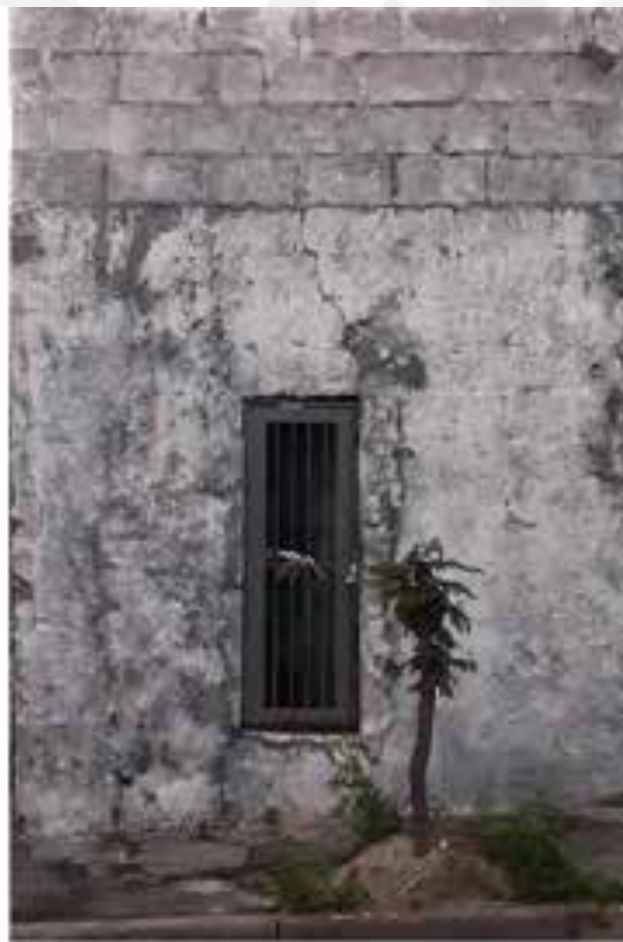

Figura "

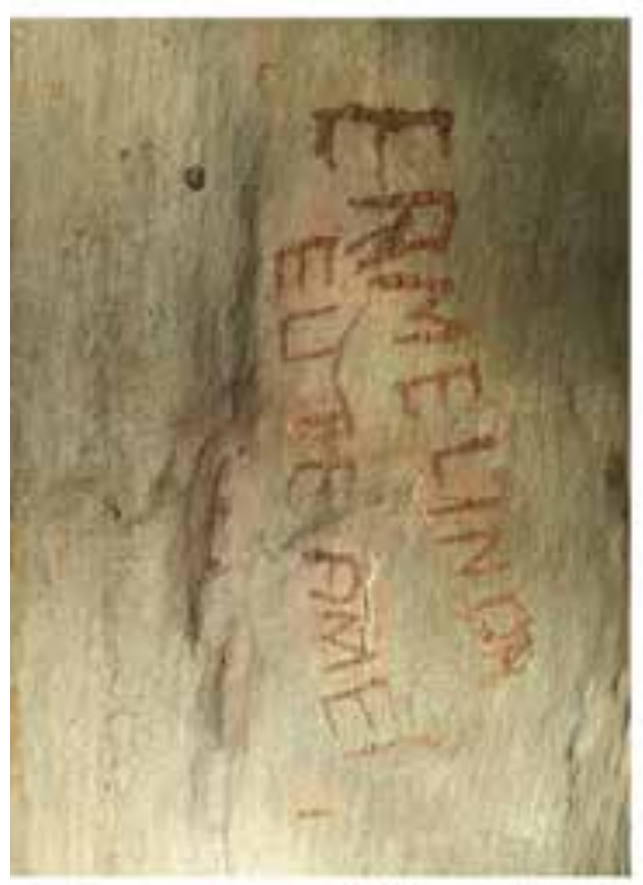

Figurd 12

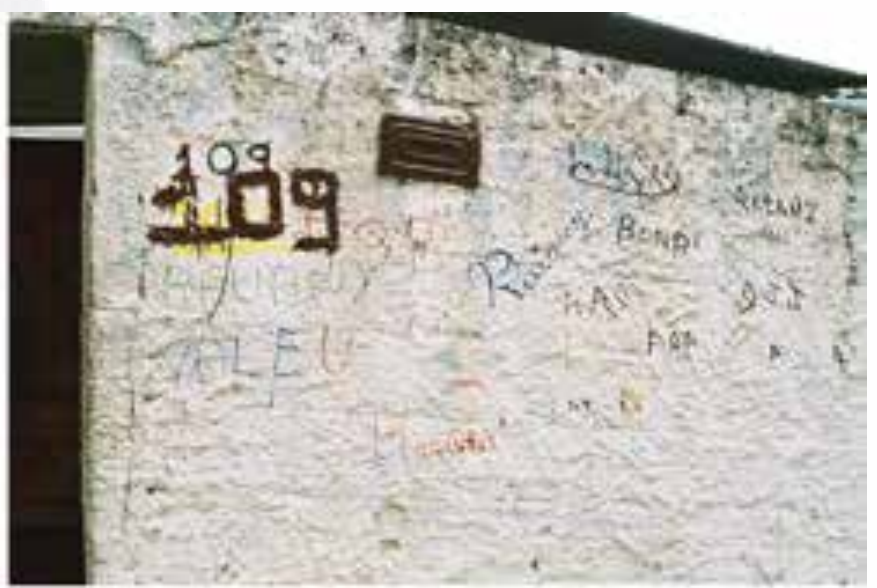

figura 13: Valeu, Rayani, Bonal, hAS, Lucas, 5JJ, FQP, Rosane

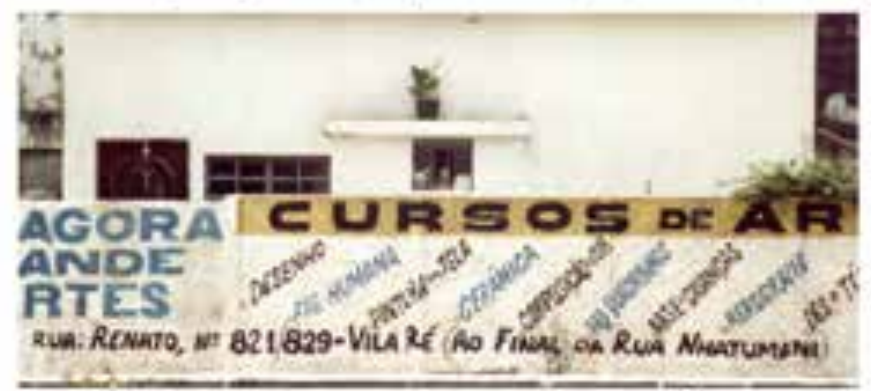

Figurd 14 


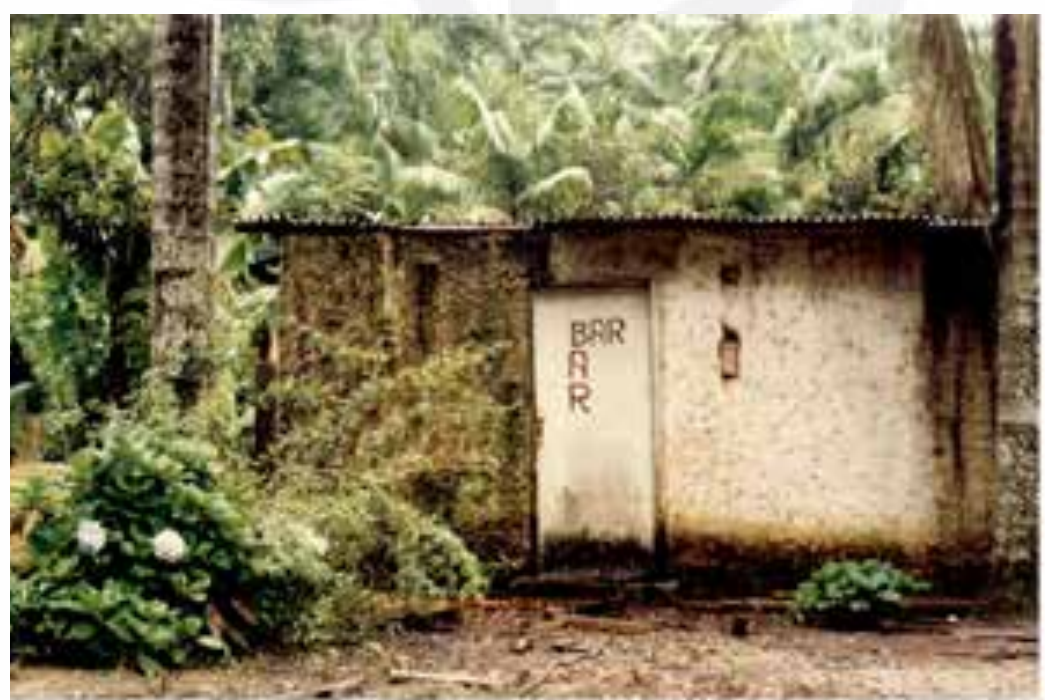

Figura 15

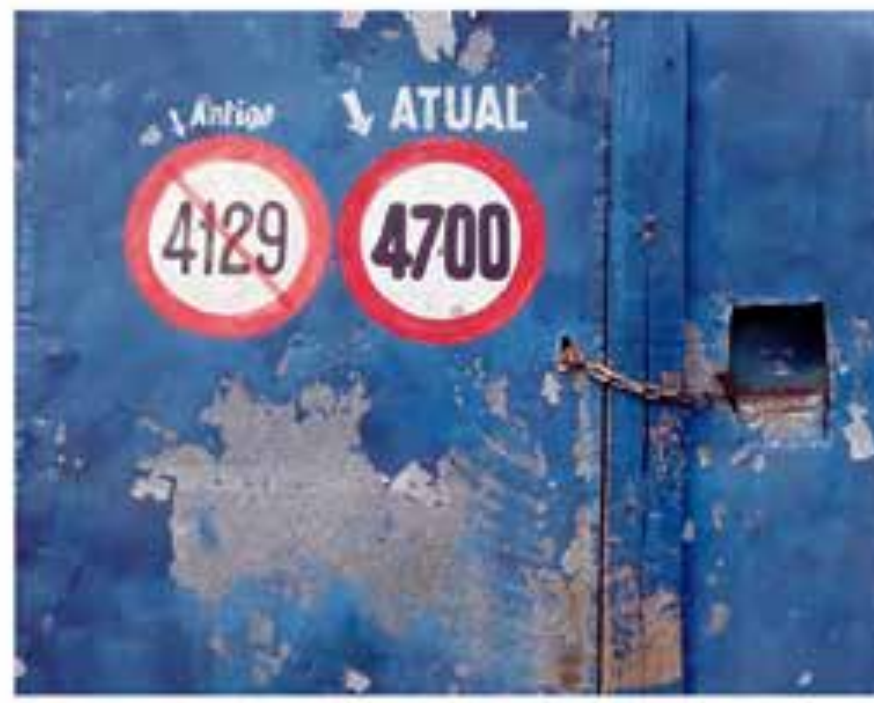

Figura 16
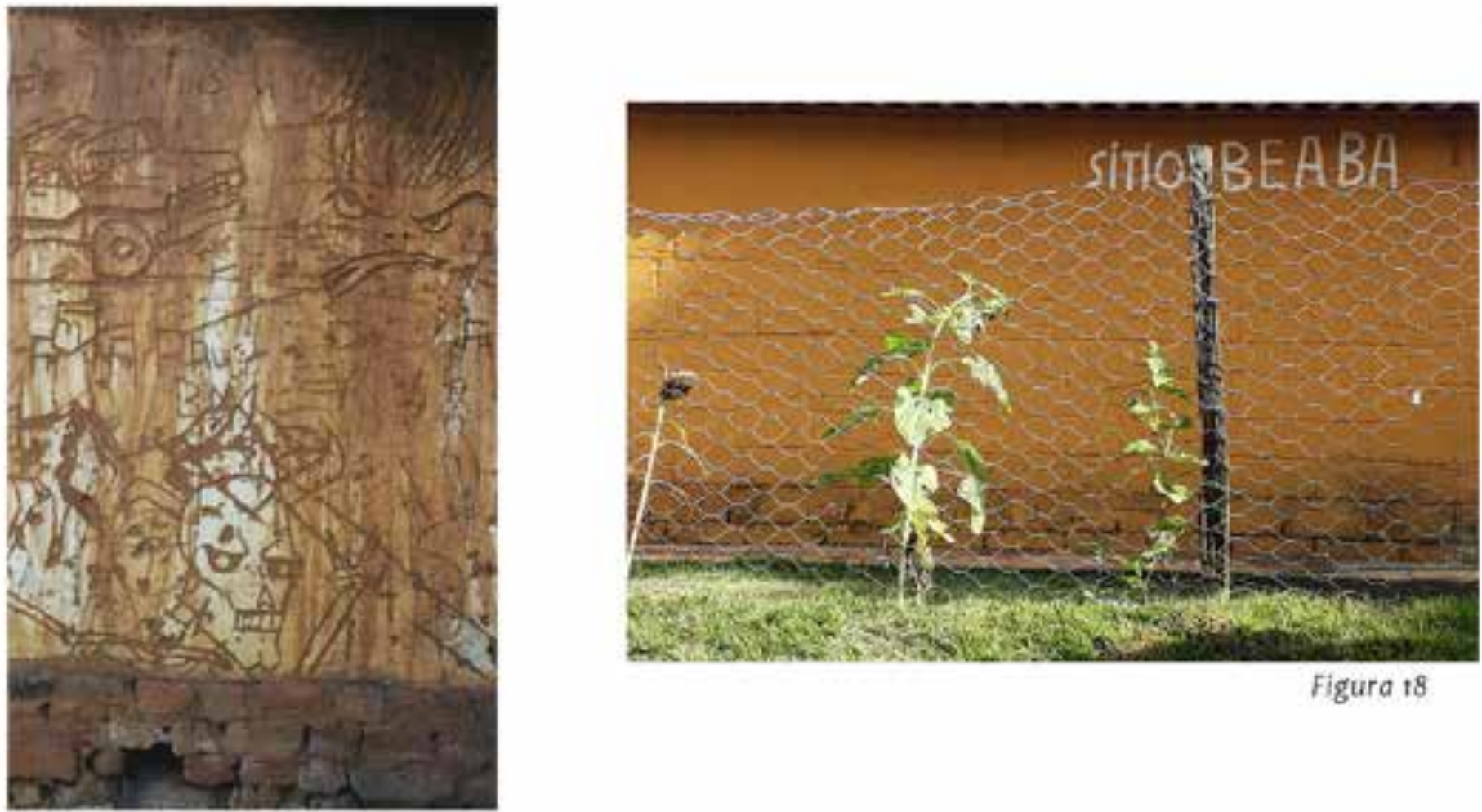

Figura 18

Figura 17: grafite de baixo relevo em taipa 


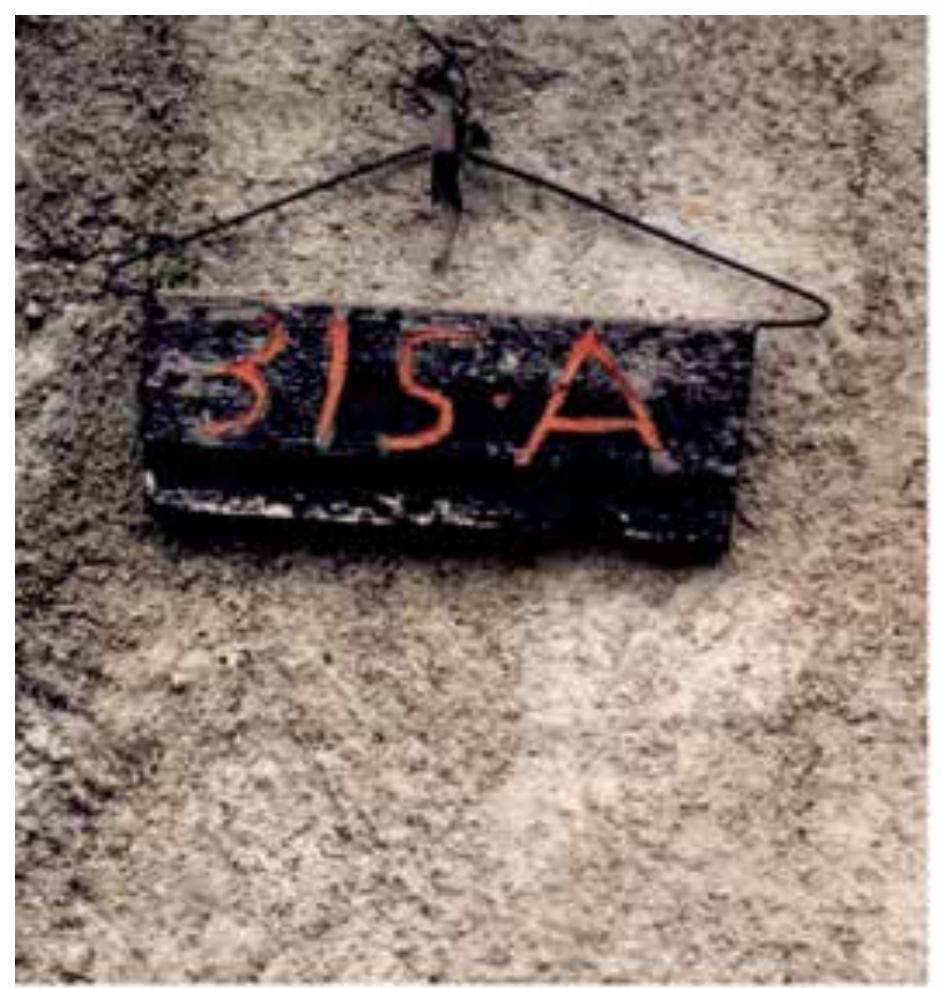

Figura 19

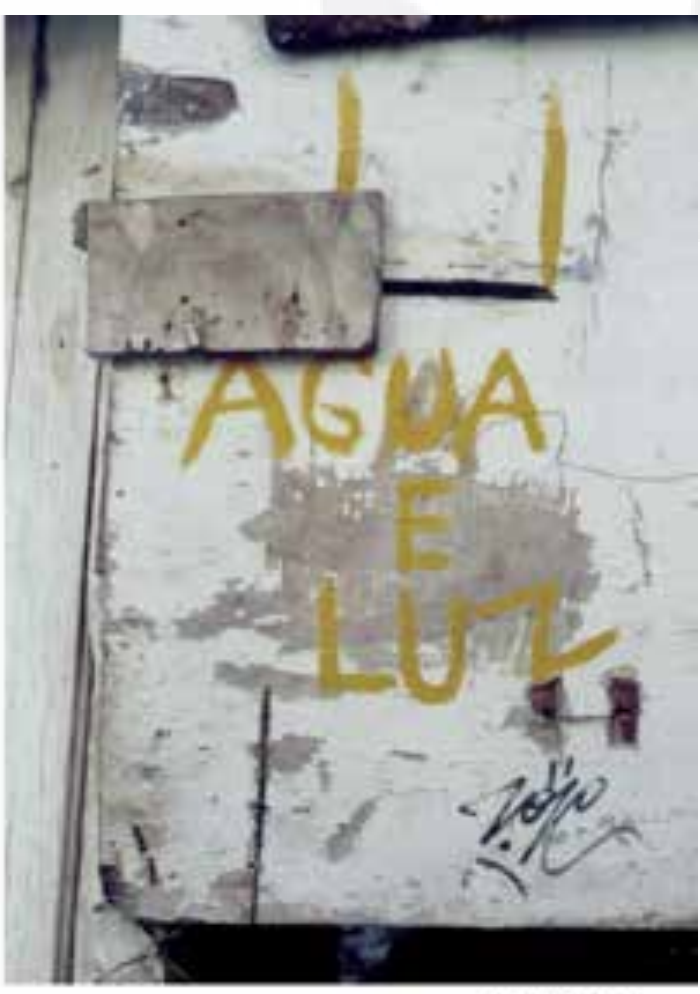

Figura 20

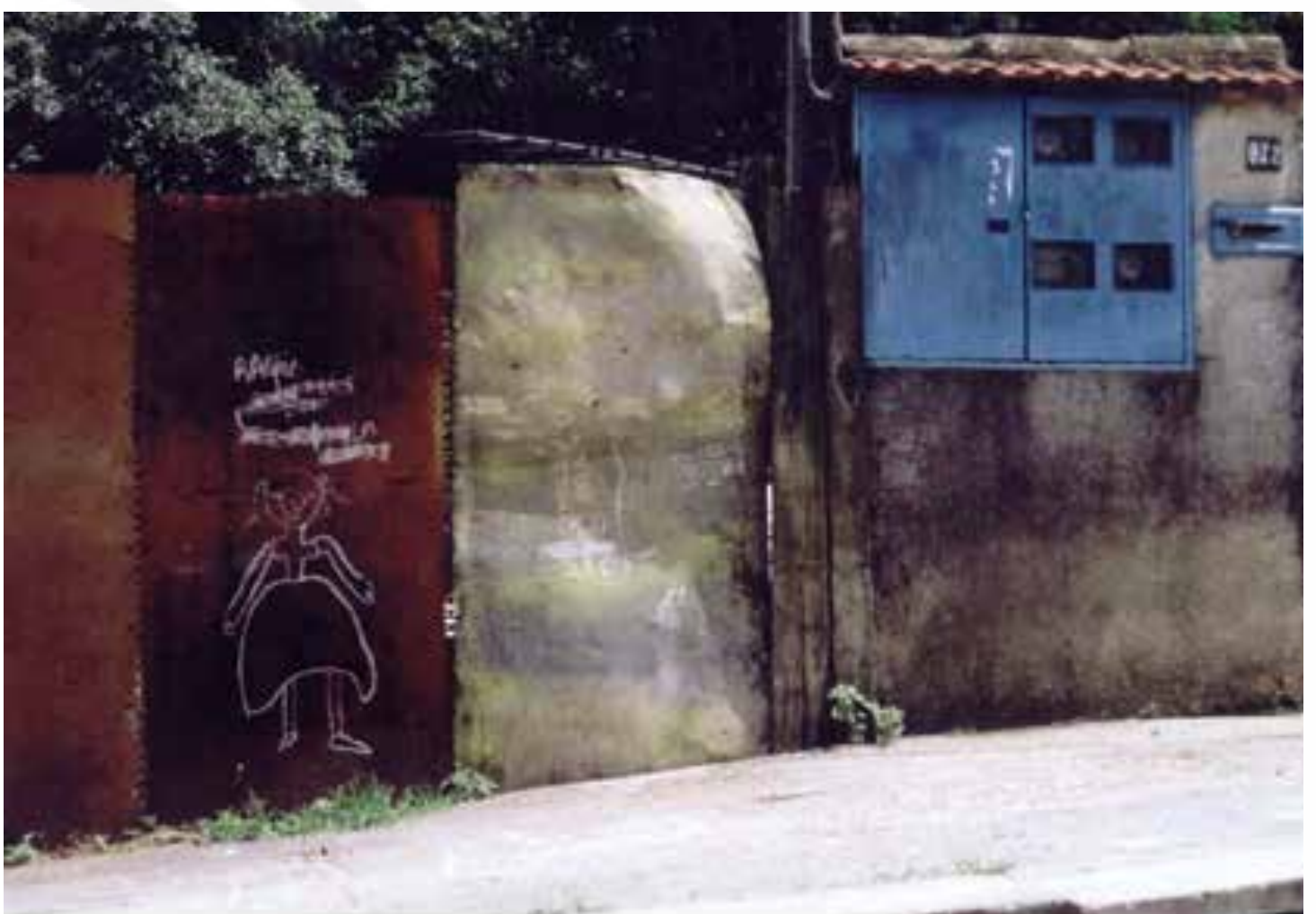

Figura 21 


\section{Rural e urbano}

O confronto do urbano com o rural é armadilha quase inevitável. Não se identifica, entretanto, ao mudar o olhar deste para aquele, alteração da própria atitude estética. As formas do campo, composição "fractal", versus as da cidade, composição "esquadro", aparentemente tão distintas, não se diferenciam de fato na busca da abstração. No tema talvez não se possa dizer o mesmo, já que a própria ocupação do espaço é distinta. Na cidade o espaço é exíguo, para as camadas menos favorecidas, e no campo ele sobra. Na cidade é mutante. No campo, permanente. Na cidade, realidade. No campo, idílio.

E, em qualquer canto, estão as marcas dos miúdos.

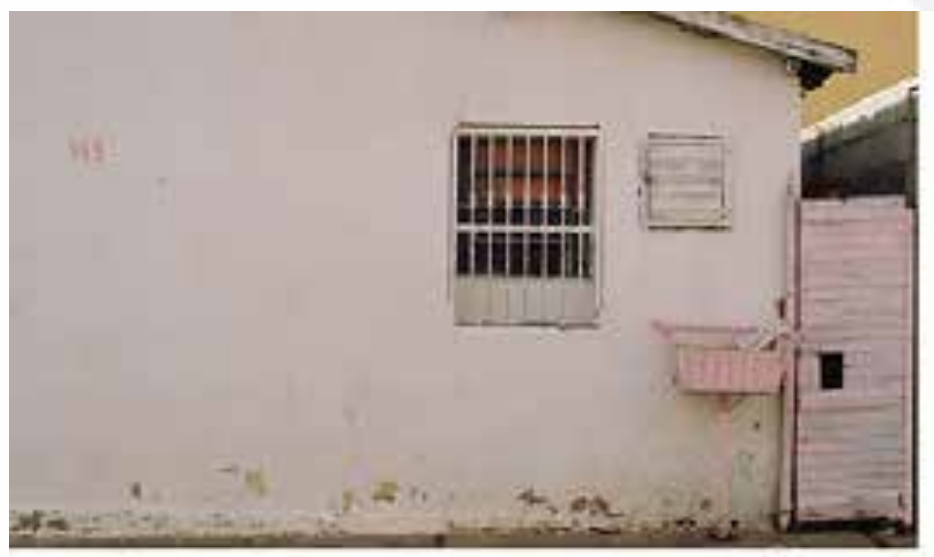

Figura 22

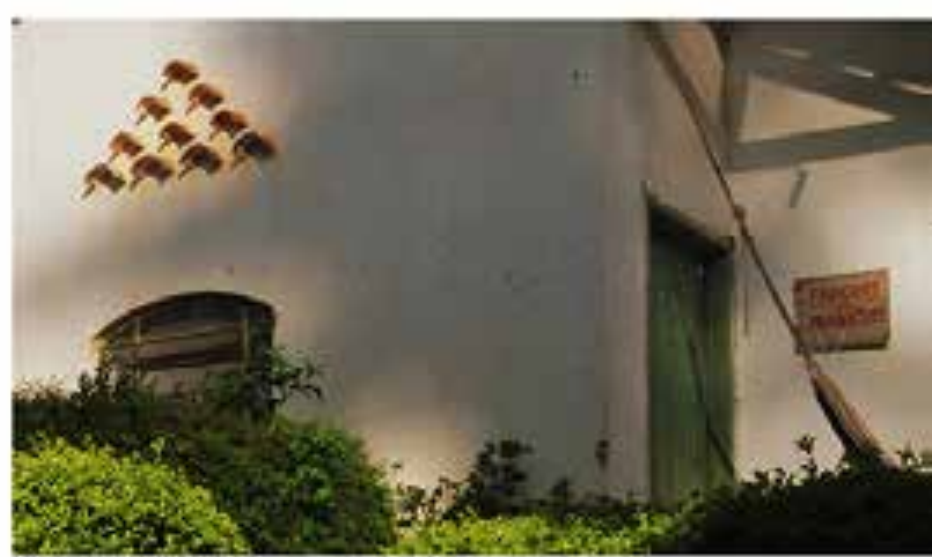

Flgura 23

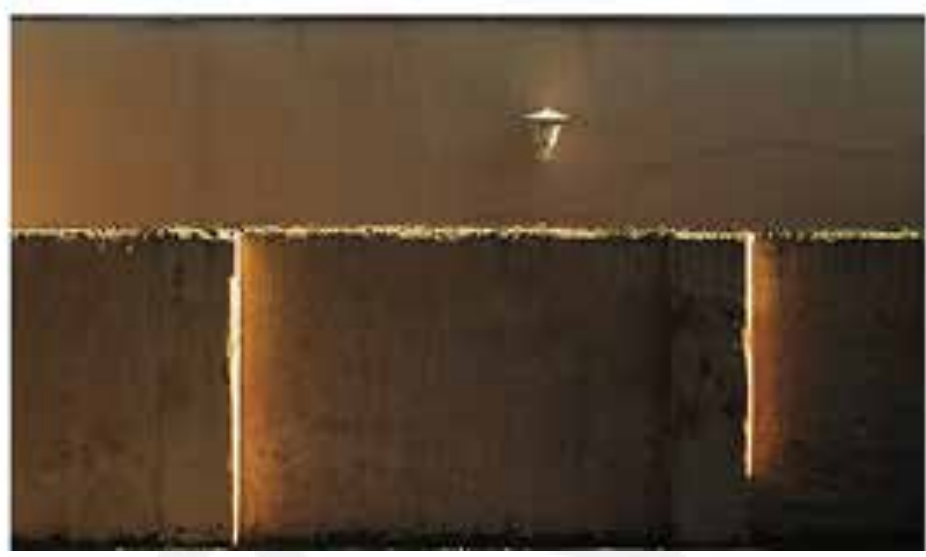

Figura 24: De onde vêm e o que veem 


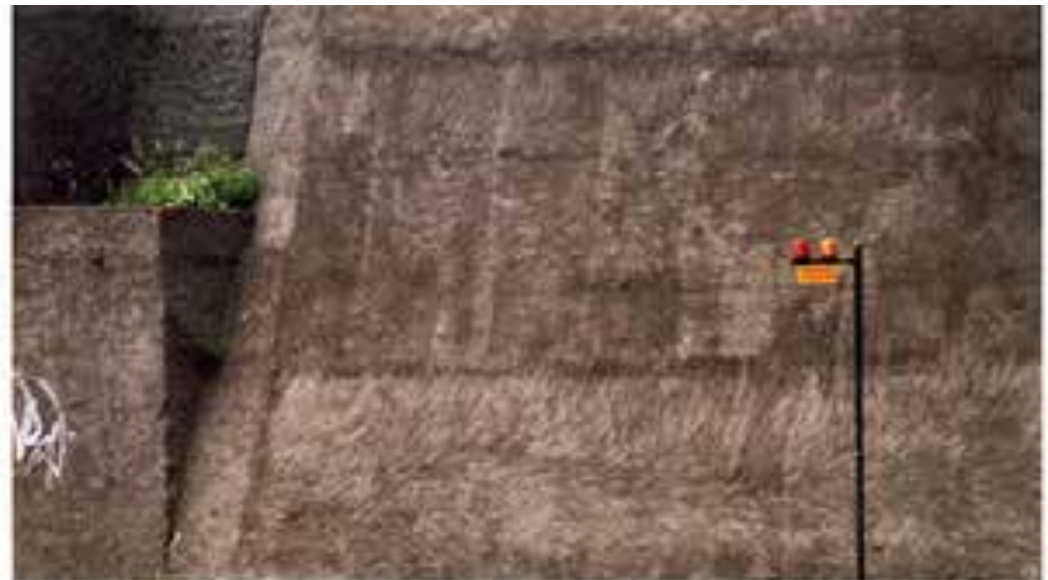

Figura 25

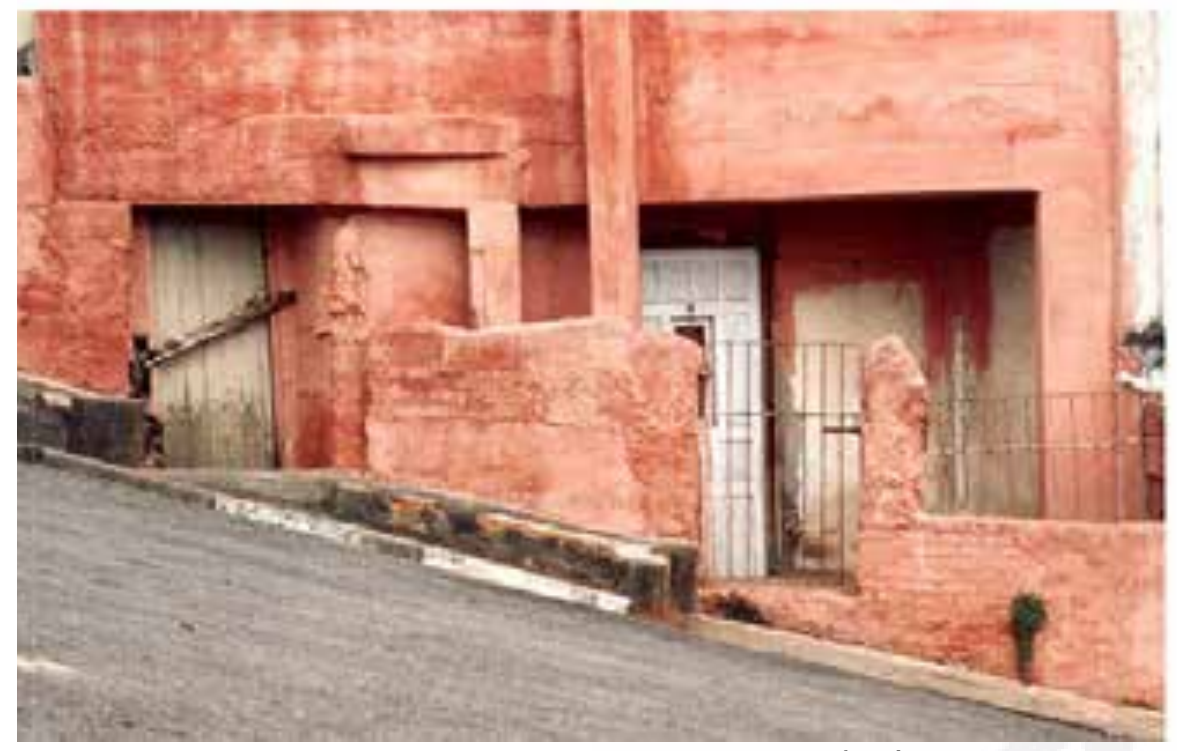

Figura 27: De onde vêm e o que veem

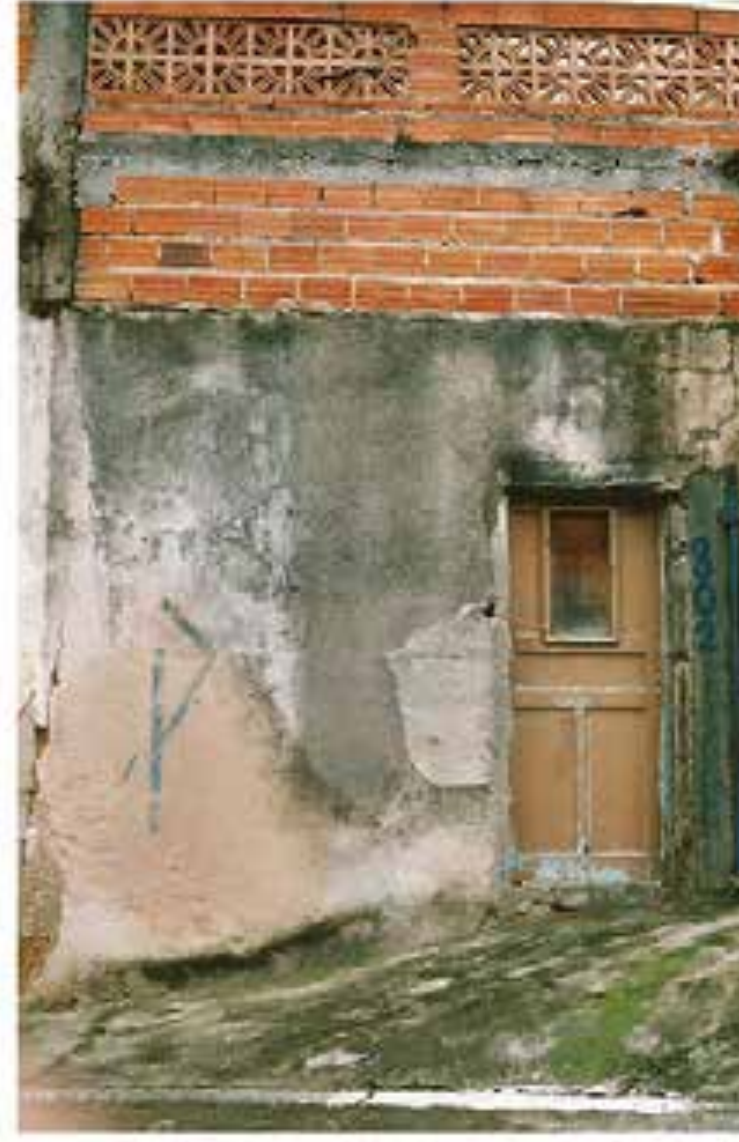

Figura 26 


\section{Para o muito alto}

Independente da fé de quem registra, as formas populares de manifestação da crença no sagrado são sempre encantadoras: o salmo pintado na pedra da beira do caminho; a maçã de amarração de amor, Eva de matriz africana, em cama de flores do chão; ou a pequena capela de múltiplas crenças, sincrética, lembrança da morte de alguém em desastre de carro naquele ponto da estrada, invadida pela trepadeira. Tudo é doçura.

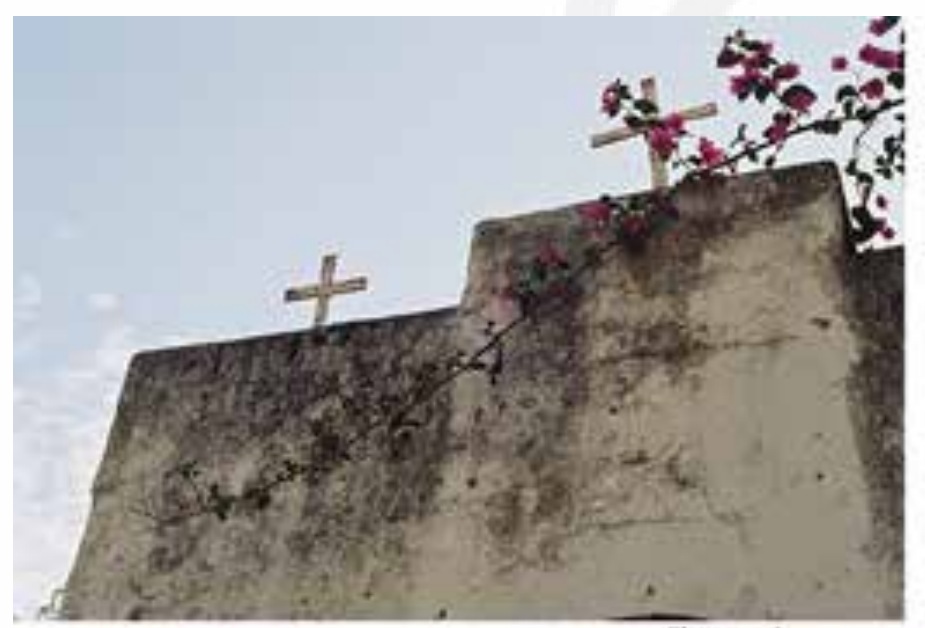

Figuta 28
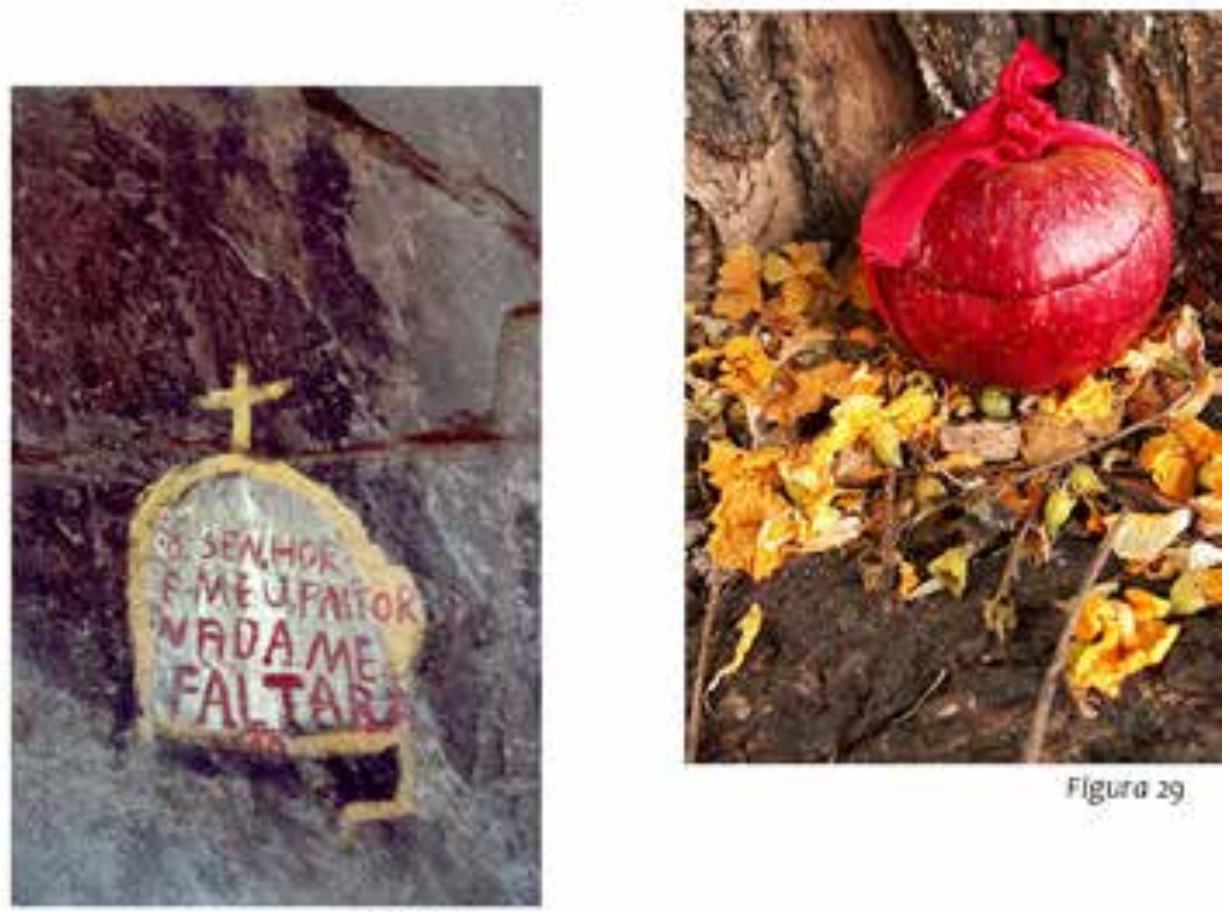

Figura 29

Figura 30 


\section{A dona da casa virada em dona da cidade}

Uma das maiores transformações do século $X X$, a condição social da mulher traz alterações significativas para a paisagem urbana. A outrora protagonista quase exclusiva da vida privada realizou importante movimento em direção à vida pública, embora não tenha (ainda?) abandonado o privado na (des)medida masculina.

A fotografia urbana se influencia por esse fenômeno, tanto naquelas em que as mulheres são representadas, em que aparecem no mais das vezes sozinhas ou acompanhadas de outras; quanto naquelas em que as marcas de sua passagem ou ausência se fazem notar, como no menor cuidado recente às manutenções das casas.
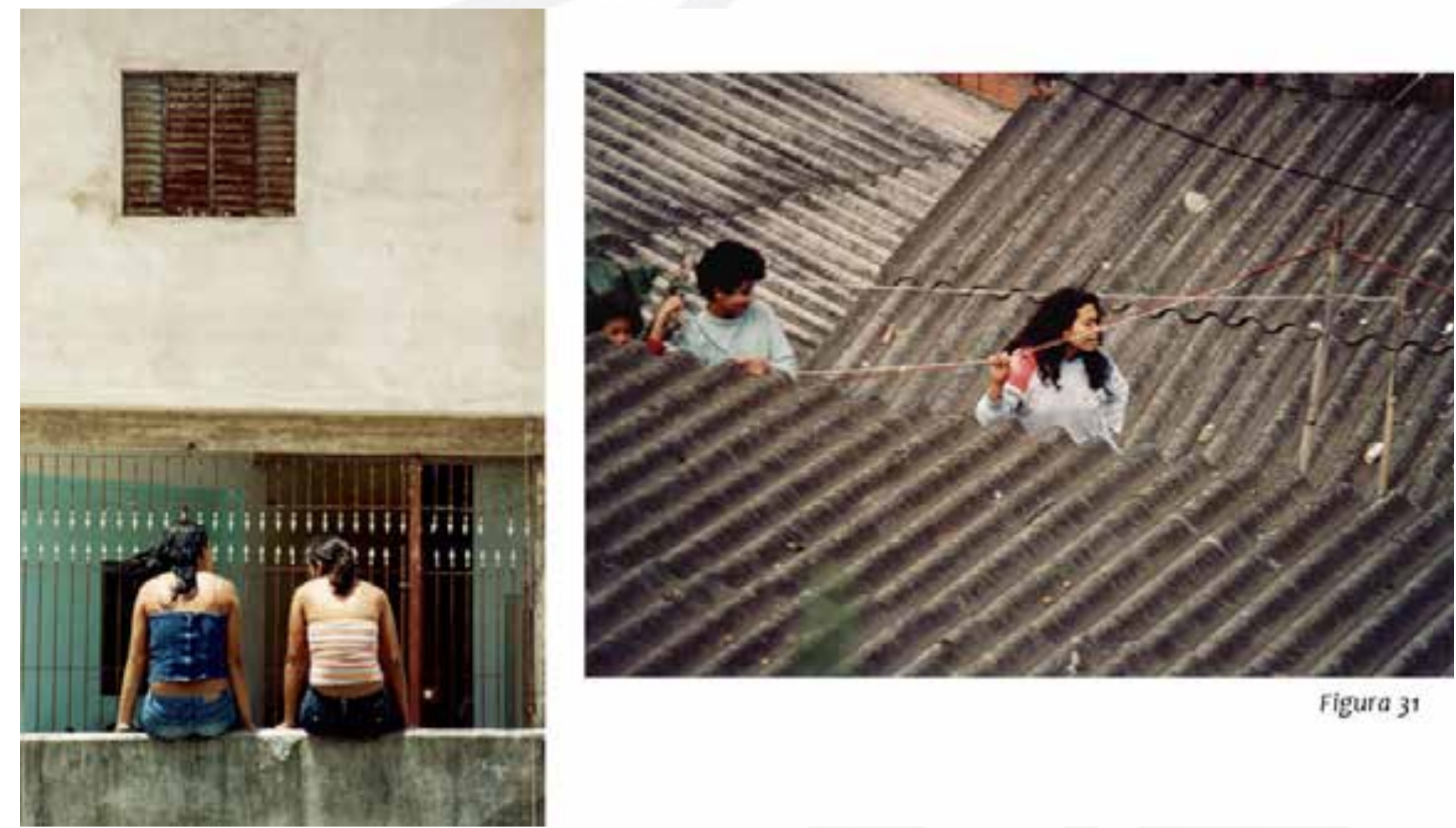

Figura 31

Figura 30: Antes era sozinha na janela 


\section{Do alto}

No espaço privado a tecnologia ocupa posição dominadora. Em cada cômodo da casa há sempre dois ou mais dispositivos eletrônicos, mas essa dominação tem expandido seus tentáculos para fora. Nas ruas das cidades, não mais são livres as corruíras.

Sorrateiras, imaginavam-se solitárias ou cercadas de iguais no seu ciscar. Agora já sabem que, em cada alto, há uma câmera que, sob o pretexto de protegê-las e à cidade, na verdade as vigia. Não há mais clandestinidade peralta nos seus atos.

Em cada ponto, uma máquina delatora. Só o grande número protege os miúdos que, anônimos e encapuzados, perdem-se na multidão.

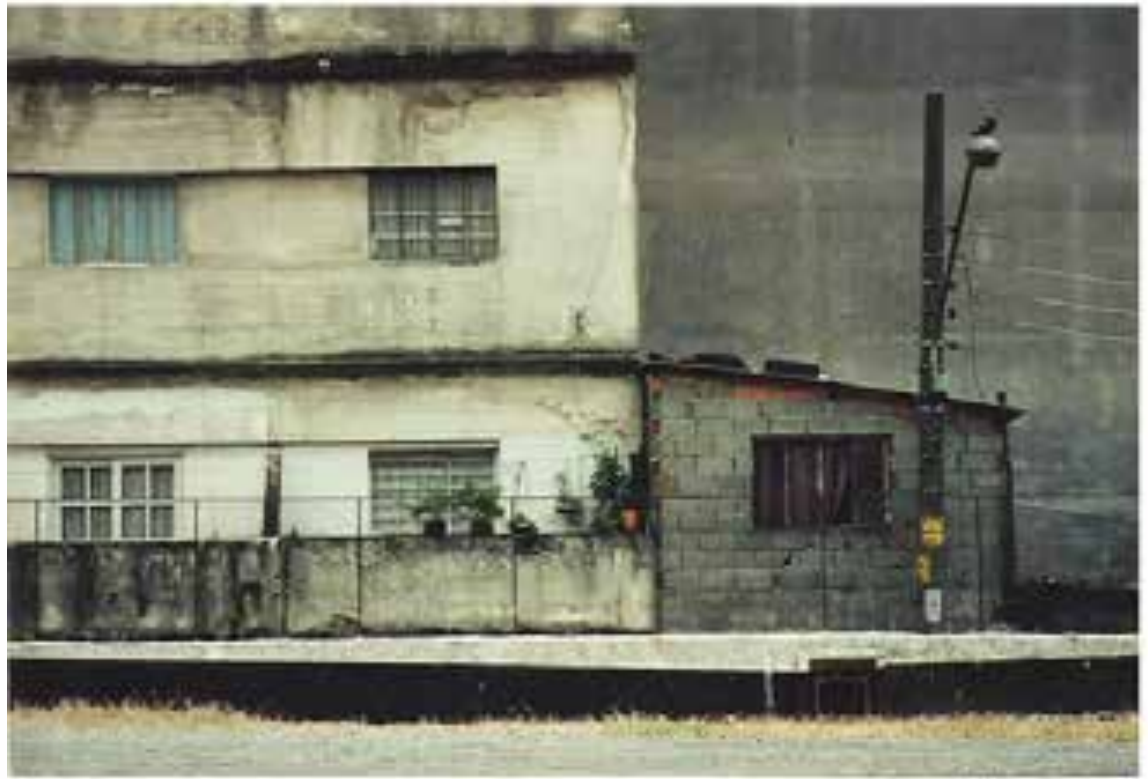

Figuro 32

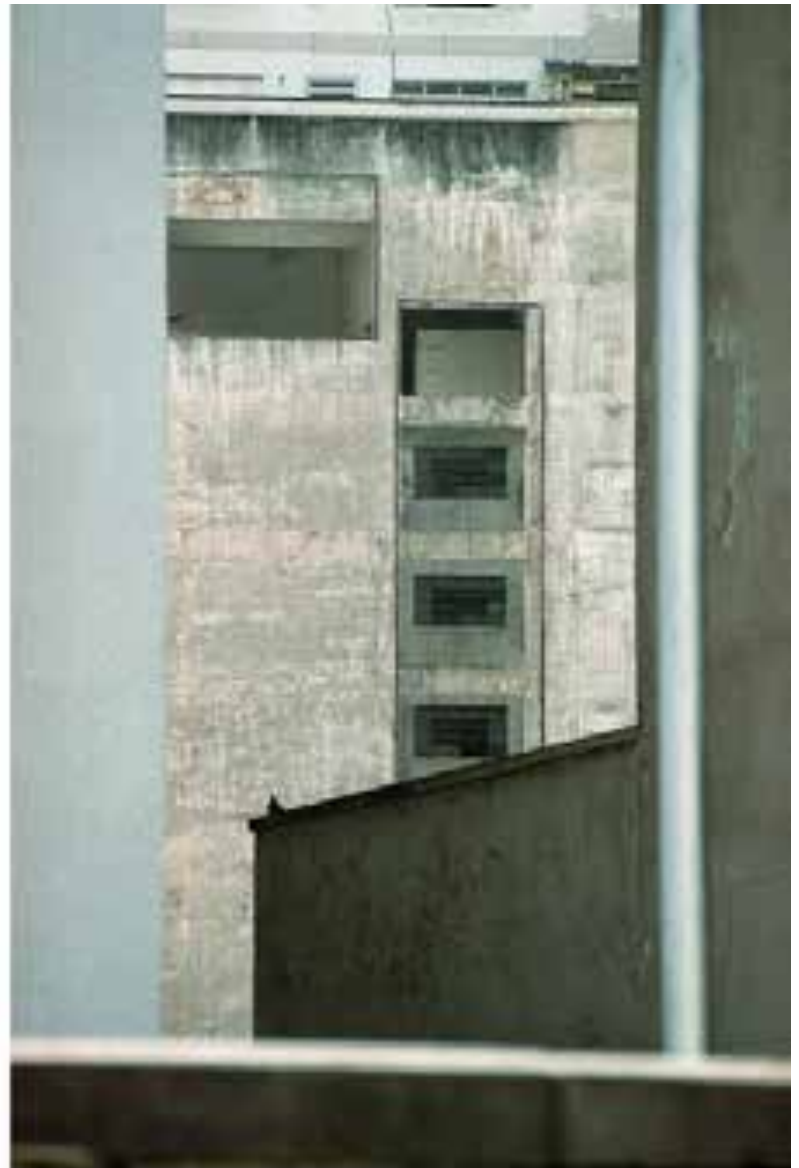

Figura 33 


\section{Por fim}

A identificação dos fundamentos do espaço praticado pela população economicamente menos poderosa, quando se olha por esta fotografia, mostra que é apenas aparente o efeito do tamanho da cidade ou da condição rural versus urbana da mesma. Ficam mais claras, nas marcas das ruas, as influências da improvisação das necessidades da vida diária e o atrevimento estético, religioso e de encontro entre as pessoas, com que a população de corruíras ousa invadir o espaço institucional, armada de suas inconveniências de classe desfavorecida.

\section{REFERÊNCIA BIBLIOGRÁFICA}

SARAMAGO, José. Levantado do Chão. São Paulo: Companhia das Letras, 2013. 